\title{
Springtails (Hexapoda: Collembola) of some plant communities of the Pechora delta
}

\author{
Ногохвостки (Нехарода: Collembola) растительных сообществ \\ побережкья дельты Печоры
}

\author{
A.A. Taskaeva, A.A. Kolesnikova, G.L. Nakul

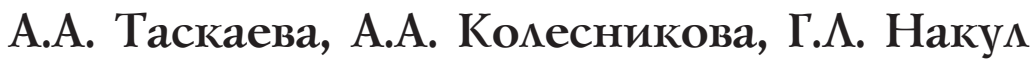

Institute of Biology, Komi Science Center, Ural Branch of Russian Academy of Sciences, Kommunisticheskaya str. 28, Syktyvkar 167982, Russia. E-mail: taskaeva@ib.komisc.ru

Институт биологии Коми научного центра Уральского отделения РАН, Коммунистическая 28, Сыктывкар 167982, Россия.

KEY WORDS: springtails, diversity, Pechora sea coast, North-Eastern Europe.

КЛЮЧЕВЫЕ СЛОВА: ногохвостки, разнообразие, побережье Печорского моря, Северо-Восточная Европа.

ABSTRACT. A quantitative study of collembolan assemblages on the Pechora Bay coast was performed. Altogether, 81 species of springtails from 43 genera and 15 families were registered. Among them four species are noted for the first time in East European tundra. The boreal species prevailed, only four true arctic forms were found. The springtail population of the studied tundra landscapes is characterized by a very high degree of dominance of a few mass species inhabiting a wide range of diverse communities, which indicates insignificant differences of these assemblages between plant ecosystems.

РЕЗЮМЕ. Поведено обследование фауны и населения ногохвосток основных растительных сообществ побережья Печорского залива. Всего в данном районе обнаружен 81 вид ногохвосток из 43 родов и 15 семейств, четыре из которых впервые отмечены для восточно-европейских тундр. Преобладают бореальные виды, арктический комплекс выражен слабо и включает только четыре вида. Население ногохвосток исследованных тундровых ландшафтов характеризуется очень высокой степенью доминирования немногих массовых видов, заселяющих широкий спектр разнообразных растительных сообществ. Это указывает на незначительные различия сообществ коллембол между растительными экосистемами.

\section{Introduction}

Last years there is an increased interest in inventory and assessment of species richness levels of certain areas, countries, natural zones and the whole world [Chernov, 2002]. These data are considered as a necessary basis for development of principles and technologies of biological diversity conservation. Due to this context the arctic and subarctic territories are especially of interest. Information about what is happening in ecosystems with an increase of anthropogenic impact on native landscapes in high latitudes is important for understanding of the general trends and mechanisms determining biotic reactions complexes for negative effects.

The Pechora Delta region and the neighboring East-European tundra's are the most important landscape complexes of the European North-East of Russia. The unique character of the Pechora Delta nature complex and its flora and fauna, was already noticed by F.V. Sambuk as far back as in 1929 [Pechora Delta, 2000]. This area belongs to the tundra zone, but the presence of the Pechora Delta leads to intrusion of boreal plant and animal species into the region. The region's unique natural landscape complexes are determined by the close relation to the Pechora River and by the geological history of the territory. The simultaneous existence of boreal, tundra and intermediate ecosystems on a rather small territory determines the unique species and community diversity of the Pechora landscapes.

Despite the inaccessibility, the faunas of two arthropod groups, namely spiders and beetles have been studied more or less completely [Pechora Delta, 2000]. No special study of springtails have been carried out in the tundra areas of Pechora Bay. The available material has been until recently restricted to faunistic collections on the Kuznetskaya and Bolvanskaya Bay [Babenko et al., 2017]. Thus, the main goal of this work is the primary inventory of the local fauna of this region.

How to cite this article: Taskaeva A.A., Kolesnikova A.A., Nakul G.L. 2020. Springtails (Hexapoda, Collembola) of some plant communities of the Pechora delta // Russian Entomol. J. Vol.29. No.4. P.343-349. doi: 10.15298/rusentj.29.4.01 


\section{Materials and methods}

The lower Pechora region is situated in the northeastern part of European Russia. The Pechora lowland is bordered by elevated areas, the Ural mountains in the East and the Timan Ridge in the West and South-West. The vegetation cover in the lower Pechora Delta consists mainly of communities typical for the southern or subarctic tundra zone, also referred to as shrub and tussock tundra [Chernov, Matveyeva, 1997]. Especially elevated areas within the region also include communities characteristic for the typical tundra zone. The southern tundra zone is the dominant subzone of the tundra in north-east European Russia stretched along the coast of the Arctic Ocean. According to the climate map of the Nenets Autonomous Region this area is located in the subarctic climate zone. Climatic conditions in this zone are determined by the amount of solar irradiation, the radiation balance, intensive air convection streams and a noticeable influence of the Arctic Ocean. The region is characterized by an excess moisture regime. The average longterm precipitation amounts to $450 \pm 90 \mathrm{~mm}$, distributed over $211 \pm 45$ days during the year. The temperature regime shows large seasonal fluctuations. The long-term 24 -hour average temperature varies from $-20^{\circ} \mathrm{C}$ in January to $13^{\circ} \mathrm{C}$ in July [Pechora Delta, 2000].

The quantitative surveys were carried out in the Malozemelskaya and Bolshezemelskaya tundra. On the coast of the Malozemelskaya tundra six local faunas were studied. The first two points are situated in Pechorskaya Bay: 1 . Khabuika - the coast of Zakhrebet Bay, the vicinity of the village Khabuika; 2 . Lovetsky - an island $\left(41 \mathrm{~km}^{2}\right)$ is washed by Pechora sea in the north and Korovinsky Bay in the south. The other four points are located in Korovinskaya Bay: 3. Sanev; 4. Kashin — island is not big but with a significant height difference; 5. cape Erennoy Nos; 6 . Kostyanoy Nos - peninsula between Korovinskaya and Srednaya Guba. On the coast of the Bolshezemelskaya tundra only one local fauna was studied: Bolvansky Nos peninsula between the river Bolshaya Pechora and Bolvanskaya Bay (Fig. 1). The territory is situated in the

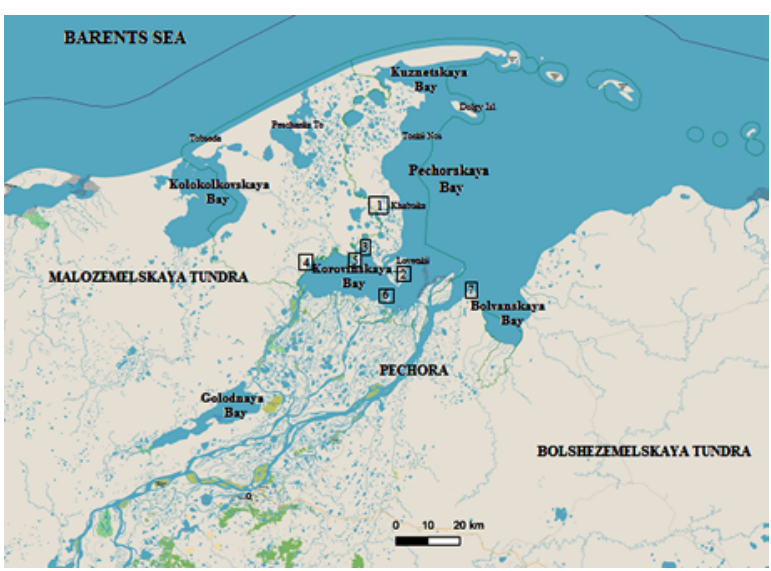

Fig. 1. Localities within the region under consideration. Рис. 1. Изученные локалитеты региона. subzone of the southern tundra excluding Khabuika related to typical tundra [Yurtsev et al., 1978].

Data were collected during the 1999-2000 period in the framework of a joint project "Delta Pechora" with the RIZA in Lelystad, the Netherlands and also in 20012003, 2010, 2019 during field works of Institute of Biology. The full sampling event dataset is published in GBIF [Taskaeva, 2020]. The following plant associations, more or less completely reflecting the diversity of vegetation were studied [Kulyugina et al., 2005]:

1. The zonal dwarf shrub-lichen tundras represent the main plant association in the study area. They form contours with large areas, situated in high points of the relief, placrusts on sandy and peat soils are characteristic of all studied points. Empetrum hermaphroditum, Ledum decumbens, Arctous alpina dominate in the grassy shrubby layer. The height of the moss-lichen layers 15-20 cm, where Flavocetraria nivalis, Cladonia arbuscula, C. rangiferina, Cetraria islandica and green mosses refer to the dominating complex.

2. Willow-yernic communities are characteristic of gentle slopes, places with sandy, loamy and peaty soils. They form small areas and presented by Betula nana and Salix glauca. In the herby-shrubby Empetrum hermaphroditum, Vaccinium vitis-idaea, V. uliginosum, Ledum decumbens, Equisetum arvense are most abundant. For the ground layer which is $10 \mathrm{~cm}$ thick Cladonia spp., Stereocaulon paschale, Peltigera aphthosa prevail.

3. Grass and herbs meadows situated in flood-lands are rare. Alopecurus pratensis, Bromopsis inermis, Festuca rubra, Poa pratensis are the main dominating species.

4. The hygrophilous sedge-potentilleae communities are situated in the lowlands of the relief, swampy lowlands next to channels and along banks of lakes, in shallow waters. For them the excessive dampening, the absence of frozen earth, loamy soils are characteristic. Carex aquatilis is the dominant.

5 . The alder communities are founding the relief lowlands along the banks of water reservoirs, in flowing narrows where they form contours with small areas. Duschekia fruticosa, Salix lunata, S. glauca dominate in these communities. Forbs prevails here (Equisetum sp., Carex aquatilis, Ranunculus repens) as and grasses (Poa pratensis).

6 . The tidal strips.

Quantitative surveys of soil-dwelling microarthropods were carried out in all the above habitats (samples of $5 \times 5 \times 5 \mathrm{~cm}$ or $10 \times 10 \times 5$, usually in $5-10$-fold replicate). The springtails were extracted from the soil samples in the laboratory during 7-8 days without additional heating. In all, 135 soil samples were processed, from which over 25 thousand specimens of collembolans were extracted and identified [Fjellberg, 1998, 2007; Potapov, 2001; Kaprus et al., 2016; Babenko et al., 2017]. The quantitative surveys in sample plots were supplemented with faunistic collections using pit-fall traps. The ordination of springtails communities via nonmetric multidimensional scaling (NMDS) using the Bray-Curtis index was based upon the number of individual collembola taxa. Statistical treatment of results was carried out with the help of PAST 3.0 programm. 


\section{Results and discussion}

\section{The fauna}

In total 81 species of springtails from 43 genera and 15 families were collected. Among them 26 species are found in the Pechorskaya Bay, 72 - in Korovinskaya Bay and 37 - in Bolvansky Nos (Table 1). For example, the local faunas of the Kolokolkova Bay (Barents Sea) and Kuznetskaya Bay (Pechora Sea) situated in typical tundra have also low diversity and include only 25 and 39 species, respectively [Babenko et al., 2017]. On the contrary, the species number of the Korovinskaya Bay is comparable with the diversity of neighboring territories. For example according to Babenko et al. [2017] in Bolvanskaya, Pakhanchenskaya and Khaipudyrskaya Guba during one season revealed 85, 90,69 collembolan species, respectively. The fauna of one of the easternmost islands of the Barents Sea region (Dolgii Island, the Pechora Sea) also shows the high level of species diversity [Babenko, 2012]. Based on this brief comparison with the data available, one may conclude that the local fauna of the study area is not diverse. But four species, i.e. Ballistura borealis, Isotomurus palustris, Folsomia fimetaria and Sminthurinus trinotatus, are noted for the first time in East European tundra. Ballistura borealis is a boreal species recorded in tidal strips of the Kostyanoy Nos, previously was registered in shores of lakes and stream banks in west Finnmark, Norway [Fjellberg, 2007]. Isotomurus palustris usually common in damp sites with standing water is also found in tidal strips of the Kostyanoy Nos. It has been recorded all over the Holarctic and often together with most of its colour forms, but its occurrence is unknown [Potapov, 2001]. Folsomia fimetaria is found in shrub lichen tundra of Khabuika. It is very difficult to explain its record, as previously this species was found only in anthropogenic soils in Vorkuta and Kola Peninsula [Babenko, 2012; Kolesnikova et al., 2019]. Sminthurinus trinotatus is characteristic species in dry and hot places and its records in Bolvansky Nos can be explained by the thawing effect of the Pechora River [Lavrinenko et al., 2016]. Also in different plant communities situated in Bolvansky Nos a synantropic Willowsia buski was found with its share about $6 \%$. According to Babenko and Fjellberg [2006] "A permanent presence of this species in the Arctic seems to be unreliable. The infrequent reports (also in the Antarctic) probably connect with sporadic introductions by humans." Thus, the checklist of springtails of East European tundra including anthropogenic soils increased to 198 species [Babenko et al., 2017; Kolesnikova et al., 2019; present study].

The great majority of the species recorded in the study area are common inhabitants of the forest belt. The specificity of the fauna is primarily determined by the large fraction of exclusively or mostly littoral forms, such as Anurida palustrus, Ballistura borealis, Folsomia sexoculata and Desoria breviseta. The last species is known from sea marshes of the Spitsbergen, Kola
Peninsula, Dolgii Island [Babenko et al., 2017]. In the zonal aspect, the fauna of the study area is a true boreal one. The inland (non-coastal) habitats in the environs of the Pechora Bay coast revealed only four arctic species, Desoria tshernovi, Folsomia bisetosa, Pseudisotoma sensibilis and Oligaphorura ursi, which were quite rare. Of the species connected to the Arctic to some extent, only Tetracanthella wahlgreni remains to be mentioned. All the other species recorded in the study area are typical boreal or polyzonal forms that commonly occur in the forest belt of Western and/or Eastern Europe. Some of these widespread species extend to the higher latitudes. To all appearances, collembolans are not the only group showing such composition of the fauna. Only two arctic species $(6 \%)$ were found among Staphylinidae and four species (4\%) among spiders [Pechora Delta, 2000]. The vascular flora of the territory has also a well-defined boreal aspect: the boreal species comprise from 39 to $49 \%$ of local floras, the hypo-arctic forms constitute $26-30 \%$, whereas the fraction of true arctic plants is not exceed 35\% [Lavrinenko et al., 2016]. The ratio of species of different latitudinal groups is determined not only by the geographical position of the territory, but also depends on the local climate and intensive migrations along the major water arteries [Lavrinenko et al., 2016].

\section{The Specific Traits of Species Assemblages}

The cenotic collembolan assemblages of the common inland habitats in the region studied are characterized by the level of species richness that is quite typical of a single survey: they include from 13 to 35 species, with the median value of 21 . The zonal shrub tundra assemblages are most diverse (60 species) due to the large number of studied biotopes at all researched points. The least diverse and quite uniform assemblages are typical for alder and sedge-potentilleae associations (Table 2). Despite the somewhat impoverished local fauna, the cenotic faunas of individual habitats of the Pechora Bay ecosystems are relatively rich in species. If we consider the results of one-time surveys similar values (18-49 species) were observed in typical tundra of the Chernaya river [Konakova et al., 2017], in southern tundra of Vorkuta [Taskaeva et al., 2019] and in forest belt of Komi Republic [Taskaeva, 2006]. But the corresponding values for the southern tundra of the Padimeiskie lakes are significantly lower [Taskaeva et al., 2015].

The density of the collembolan population during the surveys was quite similar in meadows, willowyernik and zonal dwarf shrub lichen tundra, varying from 37 to 79 thous. ind. $/ \mathrm{m}^{2}$. The abundance of springtails in these sites is compared with data obtained for such ecosystems both in typical and southern tundra [Konakova et al., 2017; Taskaeva et al., 2019]. The significant exceptions were the tidal strips, in which the abundance of collembolans was very high (371 thous. ind. $/ \mathrm{m}^{2}$ ), the sedge-potentilleae and alder plant communities, in which the numbers, on the contrary, were low (Table 2). However, the total abundance is one of the 
Table 1. The collembolan species composition of plant communities of the Pechora bay. Таблица1. Видовой состав коллембол растительных сообществ побережья Печорского моря.

\begin{tabular}{|c|c|c|c|c|c|c|c|}
\hline \multirow[b]{2}{*}{ Family, species } & \multicolumn{2}{|c|}{$\begin{array}{c}\text { Pechorskaya } \\
\text { Bay }\end{array}$} & \multicolumn{4}{|c|}{$\begin{array}{c}\text { Korovinskaya } \\
\text { Bay }\end{array}$} & \multirow{2}{*}{  } \\
\hline & 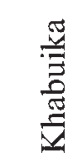 & $\begin{array}{l}: \overline{7} \\
\frac{7}{0} \\
0 \\
0 \\
0 \\
0\end{array}$ & 总 &  & 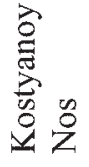 &  & \\
\hline Tullbergiidae & & & & & & & \\
\hline Mesaphorura macrochaeta Rusek, 1976 & + & + & + & & + & & \\
\hline Stenaphorura quadrispina Börner, 1901 & & & & & + & & + \\
\hline Onychiuridae & & & & & & & \\
\hline Hymenaphorura anatolii Pomorski, 2001 & & & & & + & & \\
\hline Oligaphorura absoloni (Börner, 1901) & & & & + & + & + & \\
\hline O. schoetti (Lie Pettersen, 1896) & & & + & & & & \\
\hline O. ursi (Fjellberg, 1984) & + & & & & & & \\
\hline Protaphorura bicampata (Gisin, 1956) & & & + & + & + & + & \\
\hline P. boedvarssoni Pomorski, 1993 & + & & + & + & + & + & + \\
\hline P. jacutica (Martynova, 1976) & & + & & + & + & + & + \\
\hline P. stogovi Pomorski, 1993 & & & & & + & & \\
\hline P. subarctica (Martynova, 1976) & + & & + & + & + & + & + \\
\hline P. subuliginata (Gisin, 1956) sensu Fjellberg, 1998 & + & & & & & & \\
\hline P. tundricola (Martynova, 1976) & & & + & + & + & + & \\
\hline Supraphorura furcifera (Börner, 1901) & & & & & + & + & + \\
\hline Uralaphorura schilovi (Martynova, 1976) & & & & + & + & + & + \\
\hline Hypogastruridae & & & & & & & \\
\hline Ceratophysella denticulata (Bagnall, 1941) & & + & + & + & + & + & + \\
\hline C. palustris Martynova, 1978 & & & & & & + & \\
\hline C. succinea (Gisin, 1949) & & & & & + & + & \\
\hline Hypogastrura viatica (Tullberg, 1872) & & + & & & & & \\
\hline Schoettella ununguiculata (Tullberg, 1869) & & & & & + & & \\
\hline Willemia anophthalma Börner, 1901 & & & & + & + & + & \\
\hline Brachystomellidae & & & & & & & \\
\hline Brachystomella parvula (Schäffer, 1896) & & & & + & + & & \\
\hline Neanuridae & & & & & & & \\
\hline Anurida alpina Agrell, 1939 & + & & & & & & \\
\hline A. azurea Babenko, 1997 & & & & & & + & + \\
\hline A. beringi Fjellberg, 1985 & & & & + & & & \\
\hline A. ellipsoides Stach, 1949 & & & + & + & + & + & + \\
\hline A. palustris Babenko, 1997 & & & & & + & & \\
\hline A. papillosa (Axelson, 1902) & & & & + & + & + & \\
\hline Endonura reticulata (Axelson, 1905) & & & + & + & + & + & + \\
\hline Friesea truncata Cassagnau, 1958 & & & + & + & + & + & + \\
\hline Micranurida pygmaea Börner, 1901 & & & & + & + & + & + \\
\hline Morulina gigantea (Tullberg, 1876) & & + & & & & + & \\
\hline Neanura muscorum (Templeton, 1845) & & & & + & + & + & + \\
\hline Pseudachorutes sibiricus Rusek, 1991 & & & & & & + & + \\
\hline Odontellidae & & & & & & & \\
\hline Xenyllodes armatus Axelson, 1903 & + & & + & + & + & + & \\
\hline Isotomidae & & & & & & & \\
\hline Agrenia riparia Fjellberg, 1986 & & & & + & + & + & \\
\hline *Ballistura borealis (Axelson, 1905) & & & & & + & & \\
\hline Desoria atkasukiensis (Fjellberg, 1978) & + & & & & + & + & \\
\hline D. breviseta Potapov, 2017 & & & & & + & + & \\
\hline D. hiemalis (Schött, 1873) & & & & & & + & \\
\hline D. neglecta (Schäffer, 1900) & & & + & + & & + & + \\
\hline
\end{tabular}


Family, species

D. propinqua (Axelson, 1902)

D. tshernovi (Martynova, 1974)

D. violacea (Tullberg, 1876)

Folsomia amplissima Potapov et Babenko, 2000

F. bisetosa Gisin, 1953

F. ciliata Babenko et Bulavintsev, 1993

F. fimetaria (Linnaeus, 1758)

F. longidens Potapov et Babenko, 2000

F. manolachei Bagnall, 1939

F. palaearctica Potapov et Babenko, 2000

F. quadrioculata (Tullberg, 1871)

F. rossica Potapov et Dunger, 2000

F. sexoculata (Tullberg, 1871)

Isotoma anglicana Lubbock, 1873

I. gorodkovi Martynova, 1970

I. riparia (Nicolet, 1842)

I. viridis Bourlet, 1839

Isotomiella minor (Schäffer, 1896)

Isotomodella alticola (Bagnall, 1949)

*Isotomurus palustris (Müller, 1776)

I. stuxbergi (Tullberg, 1876)

Pachyotoma crassicauda (Tullberg, 1871)

P. miserabilis Potapov, 2017

Parisotoma ekmani (Fjellberg, 1977)

$P$. notabilis (Schäffer, 1896)

$P$. reducta (Rusek, 1984)

Pseudisotoma sensibilis (Tullberg, 1876)

Tetracanthella wahlgreni Axelson, 1907

\section{Tomoceridae}

Tomocerina minuta (Tullberg, 1876)

\section{Entomobryidae}

Entomobrya nivalis (Linnaeus, 1758)

L. lignorum (Fabricius, 1793)

LWillowsia buski (Lubbock, 1870)

\section{Neelidae}

Megalothorax sp. 1

\section{Sminthurididae}

Sphaeridia pumilis (Krausbauer, 1898)

\section{Katiannidae}

Sminthurinus aureus (Lubbock, 1862)

S. igniceps (Reuter, 1881)

*S. trinotatus Axelson, 1905

Arrhopalitidae

Pygmarrhopalites principalis (Stach, 1945)

Bourletiellidae

Heterosminthurus claviger (Gisin, 1958)

\section{Dicyrtomidae}

Ptenothrix atra (Linnaeus, 1758)

Number of species

Number of biotops / samples

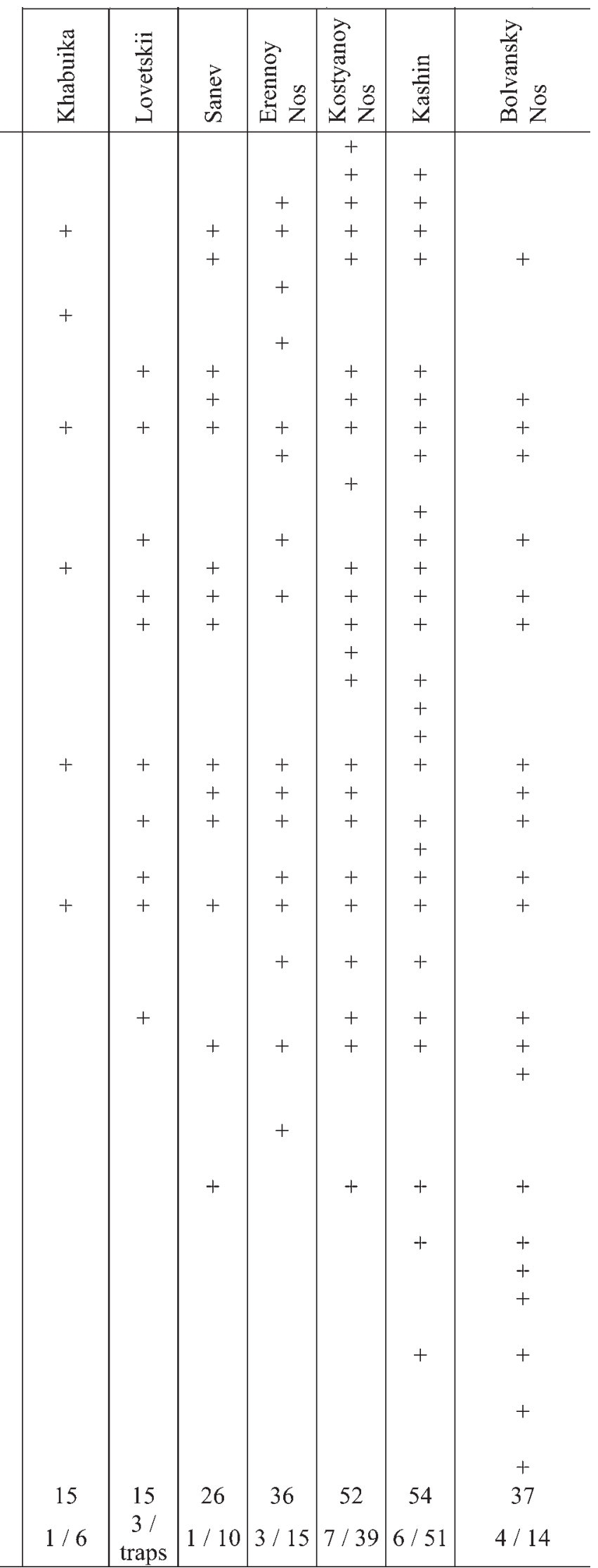

NOTE. The eudominants and dominants are shown in bold; "+" indicates the presence of a species with the relative density of less than $1 \%$. ПРИМЕЧАНИЕ. Эудоминанты и доминанты выделены жирным шрифтом; “+”обозначено присутствие вида с долей менее $1 \%$. 
Table 2. Relative abundance ( $\%$ of the total abundance) of mass collembolan species in the main plant associations. Таблица 2. Относительное обилие (\% от общей численности) массовых видов ногохвосток в основных растительных ассоциациях.

\begin{tabular}{l|c|c|c|c|c|c}
\hline \multicolumn{1}{c|}{ Species } & $\begin{array}{c}\text { Zonal tundra } \\
(\mathrm{n}=12)\end{array}$ & $\begin{array}{c}\text { Willow-yernik } \\
(\mathrm{n}=5)\end{array}$ & $\begin{array}{c}\text { Meadows } \\
(\mathrm{n}=2)\end{array}$ & $\begin{array}{c}\text { Sedge- } \\
\text { potentilleae } \\
(\mathrm{n}=1)\end{array}$ & $\begin{array}{c}\text { Alder } \\
(\mathrm{n}=1)\end{array}$ & $\begin{array}{c}\text { Tidal strips } \\
(\mathrm{n}=1)\end{array}$ \\
\hline Folsomia quadrioculata & $\mathbf{2 5 . 0}$ & $\mathbf{2 3 . 1}$ & $\mathbf{7 2 . 2}$ & $\mathbf{2 8 . 2}$ & $\mathbf{3 3 . 7}$ & + \\
Tetracanthella wahlgreni & $\mathbf{3 7 . 5}$ & $\mathbf{1 7 . 7}$ & 4.2 & 11.3 & 2.6 & + \\
Parisotoma notabilis & 1.1 & $\mathbf{1 6 . 4}$ & 3.6 & - & $\mathbf{2 5 . 5}$ & + \\
Pseudisotoma sensibilis & 7.8 & 5.5 & - & - & - & - \\
Pachyotoma miserabilis & 2.4 & 9.7 & - & - & - & - \\
Protaphorura boedvarssoni & 1.5 & 1.1 & 7.1 & - & - & - \\
Ceratophysella palustris & - & - & - & $\mathbf{2 5 . 0}$ & - & - \\
Desoria neglecta & + & - & - & 8.9 & 3.7 & - \\
Protaphorura subarctica & 1.2 & 1.0 & - & - & 9.7 & + \\
Isotomiella minor & + & 2.8 & 1.6 & - & 9.4 & - \\
Ceratophysella succinea & - & - & - & - & + & $\mathbf{6 6 . 3}$ \\
Anurida palustris & - & - & - & - & - & 10.4 \\
Desoria breviseta & + & - & - & - & - & 6.7 \\
Folsomia sexoculata & - & - & - & - & - & 6.4 \\
Mean density, thous.ind./m ${ }^{2}$ & $79.3 \pm 19.1$ & $37.7 \pm 9.2$ & $48.2 \pm 24.0$ & $9.9 \pm 1.1$ & $17.8 \pm 7.8$ & $370.9 \pm 81.1$ \\
D & 0.5 & 0.3 & 0.6 & 0.3 & 0.3 & 0.7 \\
SP (number of species) & 60 & $\mathbf{4 7}$ & 23 & 16 & 16 & 24 \\
\hline
\end{tabular}

NOTE. The eudominants and dominants are shown in bold; “+” indicates the presence of a species with the relative density of less than $1 \%$. ПРИМЕЧАНИЕ. Эудоминанты и доминанты выделены жирным шрифтом; “+”обозначено присутствие вида с долей менее $1 \%$.
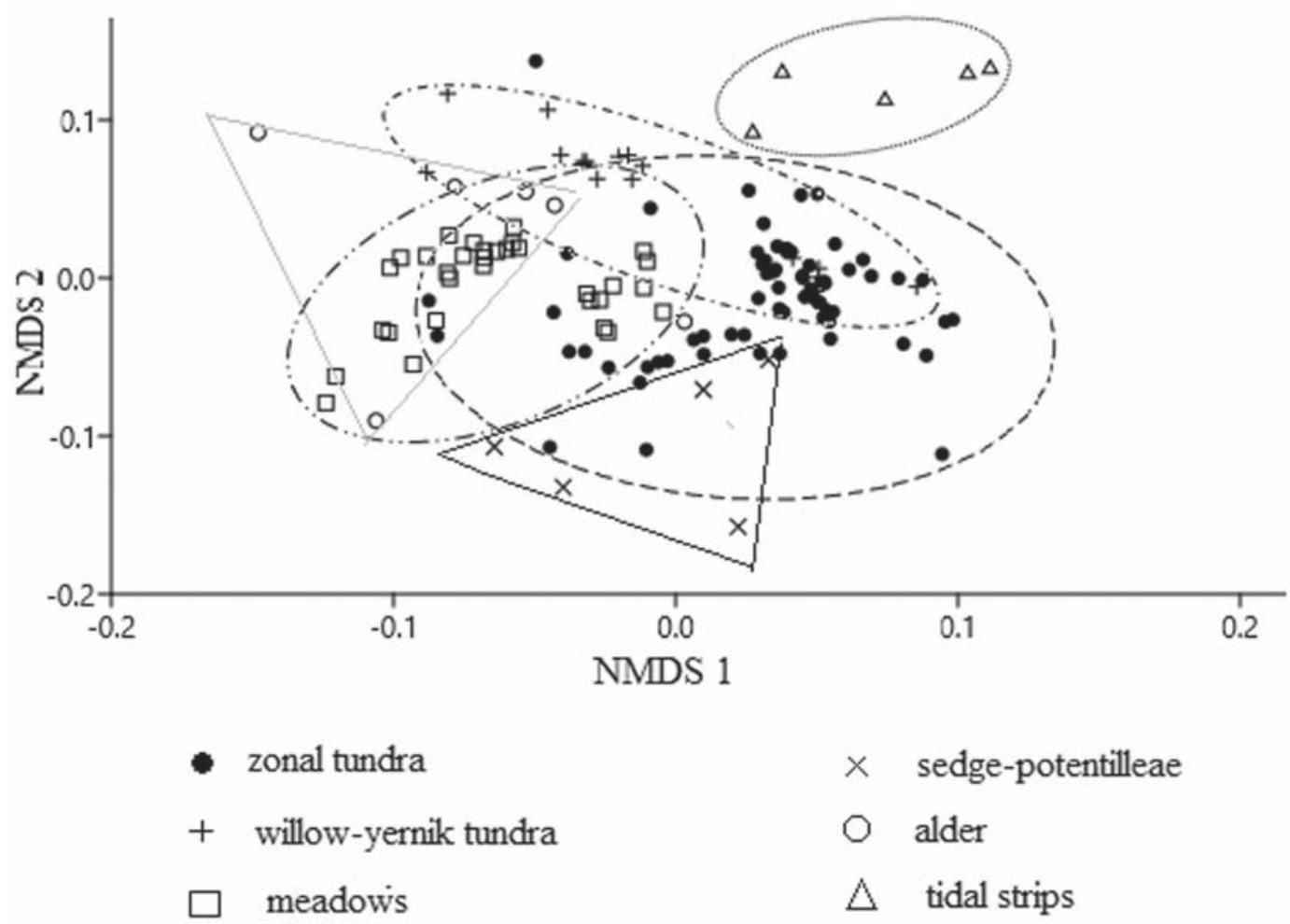

Fig. 2. Multidimensional scaling of springtails communities in the studied plots. Samples from the same phytocenoses are outlined. Рис. 2. NMDS ординация сообществ коллембол на исследованных участках. Пробы из одних и тех же фитоценозов обведены линией. 
most dynamic parameters of the soil assemblages [Kuznetsova, 2005], which strongly depends not only on the natural dynamics in a particular community but also on the method used.

A characteristic feature of most of the examined assemblages of the Pechora Bay ecosystems is a very high level of dominance of a few species (Table 2), often considerably exceeding the eudominant level (39.4\%) on the scale of Engelmann [1978]. In meadows the eudominant was the widespread ubiquitous Folsomia quadrioculata, a very common form in the East European tundra; Ceratophysella succinea was the eudominant in the tidal sprips. A more uniform distribution of species with respect to abundance were observed in the willow-yernik, alder and sedge-potentilleae associations $(D=0.3)$, though in the latter cases this may have been the result of low general population density. Moreover, all the tundra habitats showed a high abundance of Tetracanthella wahlgreni which was also found in a number of other communities in the study area. As can be expected from the high similarity of the main dominants (often also subdominants) of the assemblages studied, most of the samples overlap extensively and form a single cluster in the multidimensional scaling plot (Fig. 2). Three collembolan assemblages are the most clearly distinguished: those of the tidal strips, alder and sedge-pottentilleae associations. These communities are indeed very distinct in the landscape due to their peculiar vegetation, therefore it is quite natural that their soil complexes differ from those of the background tundra habitats.

Acknowledgments. We are sincerely grateful to E.V. Panjukova (Institute of Biology) for her help with material collection in 2019 and to anonymous reader for valuable note on manuscript of this work. The study was performed within the frames of the Russian State Research Project no. AAAAA17-117112850235-2.

Competing Interests: The authors declare no competing interests.

\section{References}

Babenko A.B. 2012. Springtails (Hexapoda, Collembola) of tundra landscapes of the Kola Peninsula // Entomological Review. Vol.92. No.5. P.497-515.

Babenko A., Fjellberg A. 2006. Collembola Septentrionale. A catalogue of the springtails of the Arctic regions. Moscow: KMK Scientific Press Ltd. 190 pp.

Babenko A.B., Potapov M.B., Taskaeva A.A. 2017. The Collembola fauna of the East-European tundra // Russian Entomological Journal. Vol.26. No.1. P.1-30.
Chernov Yu.I. 2002. [The biota of Arctic: taxonomic diversity] // Zool. Zhurn. Vol.81. P.1411-1431 [in Russian].

Chernov Yu.I., Matveyeva N.V. 1997. Arctic ecosystems in Russia // Polar and Alpine Tundra. Elsevier. P.361-508.

Engelmann H.D. 1978. Zur dominanzklassifizierung von Bodenarthropoden // Pedobiologia. Vol.18. P.378-380.

Fjellberg A. 1998. The Collembola of Fennoscandia and Denmark // Fauna entomologica Scandinavica. Vol.35. 184 pp.

Fjellberg A. 2007. The Collembola of Fennoscandia and Denmark.Part II: Entomobryomorpha and Symphypleona // Fauna Entomologica Scandinavica. Vol.42. Leiden: Brill. 264 p.

Kaprus I.J., Weiner W.M., Paœnik G. 2016. Collembola of the genus Protaphorura Absolon, 1901 (Onychiuridae) in the Eastern Palearctic: morphology, distribution, identification key // ZooKeys. No.620. P.119-150. DOI: 10.3897/zookeys.620.9372.

Kolesnikova A.A., Baturina M.A., Shadrin D.M., Konakova T.N., Taskaeva A.A. 2019. New records of Lumbricidae and Collembola in anthropogenic soils of East European tundra // ZooKeys. No.885. P.15-25.

Konakova T.N., Kolesnikova A.A., Taskaeva A.A., Nakul G.L. 2017. [Diversity of soil invertebrates in ecosystems of the Chernaya river basin, the Bolshezemelskaya tundra, Nenetskii Autonomnyi Okrug, Russia] // Euroasian Entomological Journal. Vol.16. No.1. P.88-98 [in Russian].

Kulyugina E.E., Plyusnin S.N., Elsakov V.V., Schanov V.V. 2006. Studies of biodiversity of vegetative communities: traditional and geoinformational approaches // International contact forum on habitat conservation in the Barents region: Proceedings of fourth meeting. Syktyvkar. P.342-346.

Kuznetsova N.A. 2005. [Organization of communities of soil-dwelling springtails]. Moscow: Prometei. 244 pp [In Russian]

Lavrinenko O.V., Petrovskii V.V., Lavrinenko I.A. 2016. Local floras of the islands and the southeastern coast of the Barents Sea // Botanicheskii Zhournal. Vol.101. No.10. P.1144-1190 [in Russian].

Pechora Delta: Structure and Dynamics of the Pechora Delta Ecosystems (1995-1999). 2000. / M.R. van Eerden (ed.) Lelystad: RIZA. 367 pp.

Potapov M. 2001. Synopses on Palaearctic Collembola. Vol.3. Isotomidae. Görlitz. $601 \mathrm{pp}$.

Taskaeva A.A. 2006. [Distributionof springtails (Collembola) in ecological profiles of the taiga zone of the European northeast of Russia]. Autoreferate of diss. cand. biol. sceinces. Syktyvkar. 22 pp [in Russian].

Taskaeva A. 2020. Collembola of Kolguev, Malozemelskaya tundra and Delta Pechora. Version 1.2. Institute of Biology of Komi Scientific Centre of the Ural Branch of the Russian Academy of Sciences. Sampling event dataset https://doi.org/10.15468/ 52pvpz accessed via GBIF.org on 2020-03-27.

Taskaeva A.A., Kudrin A.A., Konakova T.N., Kolesnikova A.A. 2015. [Diversity of soil invertebrates in ecosystems near the Padimeyskie lakes in the Bolshezemelskaya tundra region of Russia]//Euroasian Entomological Journal. Vol.14. No.5. P.480488 [in Russian].

Taskaeva A.A., Mandrik E.A., Konakova T.N., Kudrin A.A. 2019. Characteristics of the microarthropod communities in postagrogenic and tundra soils of the European northeast of Russia // Eurasian Soil Science. Vol.52. No.6. P.661-670.

Yurtsev B.A., Tolmachev A.I., Rebristaya O.V. 1978. [Floristic limitation of division of the Arctic] // The Arctic Floristic region: report for the symposium "Floristic limitation of division of the Arctic”. Leningrad. P.9-104 [in Russian]. 